\title{
The Effects of State Smart Grow th Management and Local Contexts on Local Open Space Preservation
}

\author{
Se Jin Lee*
}

\begin{abstract}
This study explores the effects of state smart growth management and local contextual factors - in particular, aspects of hierarchical governance and the political market framework-on local open space preservation. It takes into account state intervention in local affairs, including state requirements for local planning practices in general and for open space preservation in particular. It also tests local contextual factors such as political and informal institutions, interest groups, and community and physical characteristics, using hierarchical linear modeling. The findings suggest that counties are more likely to preserve open space when the state government strongly intervenes in local planning practices. The county manager form of government and high population density are negatively associated with open space preservation, while high demands for growth control and the presence of active environmental interest groups are positively associated with it.
\end{abstract}

Keywords: smart growth management, hierarchical governance, open space preservation, political market framework

\section{INTRODUCTION}

Smart growth has emerged as a response to undesirable urban sprawl. Urban sprawl, defined as low-density development, causes a wide range of social and environmental problems such as increased pollution, longer commutes, and loss of agricultural and environmentally sensitive areas (Anthony, 2004; Downs, 1999; Myers \& Puentes, 2001; Nelson et al., 2004; Squires, 2002). Smart growth is rooted in growth management but differs from growth management in terms of more comprehensive land use issues

\footnotetext{
* Se Jin Lee received a PhD from the Askew School of Public Administration and Policy at Florida State University. Her research interests include intergovernmental relations, collaborative governance, and local and urban politics. E-mail: sejinl@hotmail.com.
}

Manuscript received January 13, 2013; out for review February 1, 2013; review completed February 25; accepted February 26, 2013.

The Korean Journal of Policy Studies, Vol. 28, No. 1 (2013), pp. 17-41.

(C) 2013 by the GSPA, Seoul National University 
incorporating social equity concerns (Anthony, 2008; Ingram et al., 2009; Weitz, 1999).

Responding to the trend of urban sprawl, local, regional, and state governments have become increasingly concerned with the balance between growth and land preservation. State smart growth management has concentrated on mixed or higher-density development in order to protect open space and natural resources (Bosselman \& Callies, 1971; Gillham, 2002).

In the past several decades, many scholars have examined growth management with a focus on issues such as types of policies, factors leading to adoption of such policies, and the effectiveness of growth management, including at the state level. These studies have had mixed results, some finding that state growth management influences the reduction of urban sprawl while others finding no such influence. Much of the extant research is anecdotal, consisting of a simple comparison of growthmanagement states to non-growth-management states or examining the effectiveness of growth management and classifying it as weak, moderate, or strong (Anthony, 2004; Brent \& Lovrich, 2000; Carruthers, 2002; Gale, 1992; Healy \& Rosenberg, 1979; Howell-Moroney, 2007; Ketcham \& Seigal, 1991; Kline, 2000; Nelson, 1999). Most were been conducted at a single level—city, county, or state.

Under US federalism, states have the power to define the right to use land and natural resources (Nolon, 2006). Local governments not only play their own role but also cooperate and integrate with state government as implementers of state laws. In this nested system, single-level analysis cannot provide an accurate and realistic theoretical and statistical account (Raudenbush \& Bryk, 2002). Carruthers (2002) examined the impacts of growth management in metropolitan counties using disaggregated data that combined high-level units into low-level units. This leads to an analytical problem of non-independence of observations, since all counties within a particular state have identical scores on a predictor (Osborne, 2000). Therefore, this study employed hierarchical linear modeling to reduce the problem of disaggregated data.

Most extant research also does not consider political factors, including institutions and local politics, although decisions on land use policies arise from the political process (Poor \& Brule, 2007). To address this gap, this study applied the political market framework, which is an integrated theoretical framework based on institutions, the political economy of urban growth, and community and physical characteristics. The political market framework is well suited to multilevel analysis, since land use decisions are not only the result of dynamic interactions between demanders and suppliers at the local level but are also restricted by decisions made at the state level.

In sum, this study examined the effect of state smart growth policies on local open space preservation as well as the impacts of local contextual factors, using a multilevel analysis of US federalism. 


\section{GROWTH MANAGEMENT EFFORTS AND OPEN SPACE PRESERVATION}

State efforts to manage growth evolved from the environmental concerns of the 1960s and 1970s. State government took back control over land which had been granted to local government during this "quiet revolution" and became more involved in local planning. Several scholars (Carruthers, 2002; DeGrove, 1984, 1992, 2005; Ingram et al., 2009; Weitz, 1999) have chronologically categorized state growth management policies from that era to the present as follows: the quiet revolution (1969 to 1976), a second wave (1980 to 1988$)$, a third wave (1989 to 1997$)$, and the so-called smart-growth era (1998 to the present).

In the first wave, state efforts focused on regional and statewide growth management, and environmental protection programs subsided. By regulating land development, states extended their involvement in local growth management. In the second wave, growth management moved from controlling growth to planning for growth; the focus was on accommodating growth with coordinated and well-planned land use.

In municipalities during this period, growth controls involved downzoning land to limit the amount of future growth (Zovanyi, 1999). However, this was typically implemented in small suburban areas. These areas rely either economically or culturally on larger metropolitan areas. Growth control inevitably brought a spillover effect that accompanied development into parcels of surrounding unrestricted areas (Navarro \& Carson, 1991). Municipalities had concentrated on growth control by local zoning and restrictions on residential construction, leading to increasing housing values, resulting in the exclusion of low- and moderate-income residents. This exclusion was not sensitive to geographical needs, and it affected the surrounding areas. That is, state-led growth management was considered a more appealing way to offset regional and state-wide costs of environmental degradation and misuse of land.

During the third wave, which began with the adoption of statutes in Georgia in 1989, states became interested in comprehensive land-use planning. States required or encouraged local governments to enact comprehensive plans. Growth management requirements and enforcement mechanisms varied from state to state. A range of local measures including development impact fees, growth boundaries, and comprehensive plans to control growth have been implemented. Like zoning ordinances, development impact fees have distributive consequences, as their burden falls on consumers and land owners who generate distributive impacts which exclude low- and moderateincome residents (Feiock, 2004). Growth programs such as promoting new development within growth boundaries have been thought to promote the desired public ends by reducing costs for facilities and services and preserving resource lands and environ- 
mentally sensitive lands from sprawl.

In 1998, state growth management programs began to focus on smart growth (Weitz, 1999). This concept is difficult to define, since there are various approaches to it (Downs, 2005). According to Bolen et al. (2002), smart growth can be defined based on four principles: (1) elimination of state subsidies that promote sprawl, (2) promotion of infill development, (3) preservation of farmland, open space, and other areas of environmental and recreational value, and (4) support for local planning by providing incentives and technical assistance to local governments and encouraging them to enter into regional planning agreements. O'Connell (2009) defined smart growth as "promoting denser development and protecting agricultural and wild land from development." Open space preservation is a critical element in smart growth.

\section{POLITICAL MARKET FRAMEWORK}

The political market approach is a theoretical framework integrating the institutions, local politics, and growth machine theory. In order to preserve open space, political institutions interplay demands of private actors and the willingness of public officials (Clingermayer \& Feiock, 2001; Lubell et al., 2005). In the process of local decision making about open space preservation, local government institutions play a decisive role. The amount of open space preserved depends on the interaction between the demand for environmental goods, which are aggregated from residents, businesses, environmental interest groups, and homeowners, and the supply of growth management, which is aggregated by government officials (Lubell et al., 2004).

\section{Institutions}

Institutions provide the strategic context within which political actors make policy choices. North defines institutions as "the rules of the game in a society or, more formally, the humanly devised constraints that shape human interaction." Institutions can be formal and informal. According to Clingermayer and Feiock (2001), institutions include not only formal rules and formal authority but also informal norms and roles that are stable and structured. Lin (2005) asserted that informal norms and conventions can be developed in social network theory and analysis.

Based on the political economy perspective, government institutions play an important role in land use decision making, since they are the spheres in which communities' values and motives are shaped and operated. During the last 40 years, institutional influences on policy outcomes have been investigated by a number of empirical studies. 
Most of them suggest that different types of government lead to different types of policy outputs (Clingermayer \& Feiock, 2001; DeSantis \& Renner, 1994; Lineberry \& Fowler, 1967; Morgan \& Kickham, 1999). Several scholars have studied the role of professional managers and suggested that appointed managers are more responsive to environmental pressures and interests (Denzau \& Weingast, 1982; Lubell et al., 2007; Maser et al., 1977). Appointed professional county managers can afford to invest in longer-term environmental efforts because they have less risk aversion and do not face the same political constraints as elected executives (Nalbandian, 1989).

Hypothesis 1: The manager form of government will increase open space preservation.

Local legislative structure also plays a critical role in land use decisions because it creates incentives for and constraints on local land use decision making, which is carried out by the legislature. Legislative reforms centralized to establish a small legislative body typically consisting of only five members who are elected on an at-large rather than a district basis.

Cooter (2000, p. 278) argued that a larger local legislature is more likely to reflect citizens' preferences, as citizens are more likely to know their representatives and vice versa, which means that representatives are better informed about and more accepting of constituents' preferences. For this reason, a small legislature may become a barrier to effective framing of environmental interests, which tend to be more diffused and unorganized, while they may favor well-organized development interests.

Hypothesis 2: Larger commission size will increase open space preservation.

Along with executive and legislative institutions, Press (2002) contended, administrative capacity is critical to a local government's ability to preserve open space. To carry out open space protection, the government may create departments or units and may institutionalize their responsibility for open space. Many counties carry out open space programs in the planning, parks and recreation, or public works department. A county could, by creating or consolidating departments or units, give priority to open space policy. Thus, we can expect that counties with a dedicated open space office will do more to protect open space.

Open space preservation also depends on financial resources, such as the ability to issue bonds for land acquisition (McQueen \& McMahon, 2003). To carry out open space preservation, county governments have implemented local revenue collecting initiatives, including dedicating a portion of the sales tax or the property tax, impact 
fees, county budget appropriations, or general obligation bonds. Financially limited counties may look for funds from private sources or the state or federal government. Local governments require substantial financial resources to carry out land preservation. Thus, counties with more resources will be likely to increase open space protection.

Hypothesis 3: The presence of a dedicated county land preservation office will increase open space preservation.

Hypothesis 4: Counties' access to more resources will increase open space preservation.

Networks as informal institutions are important, since increased collaboration and dense network relationships have a demonstrated positive effect on performance in environment policy areas. Burt $(1992,2000)$ contended that network structure is an important element and that certain configurations bring better resources. Network closure, indicated by the number of direct connections between actors (Burt, 2000), can enhance efficiency through intensified communication. Information can freely flow in a strongly interconnected network. This facilitates common norms and values, which are critical for collective action to be achieved. It helps network members to collaborate more easily since it sanctions opportunistic behaviors (Burt, 2000; Coleman, 1990; Lin, 2005).

Erickson (2006, p. 280) noted that "rarely, if ever, are the initiators of an open-space project its sole implementer." It is obvious that dense network relationships can lead to better performance in land preservation, especially given that local governments face financial limitations. Resource exchange is important in land preservation (Press, 2000). Through cooperation with other elements of government such as federal and state agencies, county governments can access a wider range of grants, loans, and financial mechanisms to support land preservation. In addition to vertical partnerships, horizontal partners such as land trusts, environmental organizations, and private businesses are also important, since they often provide much of the detailed information about the availability of land within the government's jurisdiction. Thus, counties that have dense networks with external organizations are more likely to increase land preservation.

Hypothesis 5: Dense networks with external organizations, including federal and state agencies as well as nonprofit and for-profit organizations, will increase open space preservation. 


\section{The Political Economy of Urban Growth}

As the second element of the political market framework, the growth machine perspective sees land use decisions as the result of a political alliance between local government officials and development interests (Green et al., 1996; Logan \& Molotch, 1987). This perspective describes the relationship between local government officials and land-based elites such as developers and businesses that benefit from development and growth. Since development interests are well organized, they have an advantage over more diffused public interests, and they are often able to promote pro-development policies. Developer interests have a significant voice in land use decisions because they have more access to local power and are often well organized and financed, giving them significant influence over local development policies. Environmental interests, on the other hand, tend to be diffused, fragmented, and unorganized (Guerin et al., 2001).

Environmental interests differ from development interests in terms of the geographical basis of their organization. Although some local environmental interests involve a general concern about sprawl, many local environmental groups are associated with a specific geographical location (Lubell et al., 2005). Environmental interest groups including neighborhood organizations, homeowners associations, and citizen activists are often crucial actors in "not in my back yard" politics. They campaign against unwanted land uses or for environmental amenities such as parks and open space in their own neighborhoods.

Hypothesis 6: Stronger environmental interests will increase open space preservation.

Hypothesis 7: Stronger development interests will decrease open space preservation.

\section{Community and Physical Characteristics}

When competition for scarce land intensifies, citizen support for the provision of environmental public goods emerges. Lubell et al. (2005, p. 710) argued that "land is a common-pool resource for local communities, and as land becomes scarce, there are [benefits] to creating conservation rules that protects environmental values." As growth intensifies the scarcity of land and infrastructure, the benefits of environmental public goods such as open space (Lewis \& Neiman, 2002; Steinacker, 1998). Thus, we expect that land scarcity, sprawl, and population pressure will increase the demands for open space preservation.

Population growth patterns have been related to the demand for open space preser- 
vation and growth controls more generally. A number of studies have found a positive relationship between community growth patterns or rates and demand for growth controls (Anglin, 1990; Baldassare \& Protash, 1982; Howell-Moroney, 2004; Protash \& Baldassare, 1983).

Efforts to provide environmental public goods are also related to high socioeconomic status. According to Navarro and Carson (1991), growth management has sometimes been described as exclusionary, elitist, and status-biased. Like growth controls, open space preservation has been related to income and community social status. Romero and Liserio (2002, p. 343) found that community social status is significantly related to open-space preservation votes, and they suggested that "smaller, wealthier and whiter areas were the most likely to include open-space preservation measures."

Many studies have suggested that communities with high socioeconomic status may support growth controls to exclude low-income people (Feiock, 2004; Maser et al., 1977). Low-income populations tend to generate less support for environmental amenities. This is not due to minority populations' lack of concern for the environment, but to their lack of political resources to articulate political demands (Lubell et al., 2005, p. 711). More educated groups also show a tendency to consider preservation of open space and protection of the natural environment as highly valuable and to participate in environmental groups (Dunlap \& Mertig, 1992).

Hypothesis 8: Land area and population density and pressure will increase open space preservation.

Hypothesis 9: High socioeconomic status, including income and education levels and predominance of the white population, will increase open space preservation.

\section{Hierarchical Governance in Growth Management: Statewide Factors}

The concept of holon helps us understand a hierarchical federal system. Ostrom (2005, p. 13) defined it by noting that "what is a whole system at one level is a part of system at another level." Such nested subassemblies are part-whole units in complex adaptive systems (Koestler, 1973). Analyses dissect complex systems into composite holons that are then dissected further, and explanation occurs at multiple levels and different spatial and temporal scales.

Within the US system of government, states have the power to define and limit the right to use land and its natural resources (Nolon, 2006). Local governments play a key role in growth management policy processes, not only as innovators but also as 
implementers of state-level statutes (Steel \& Lovrich, 2000). From the "quiet revolution" in state growth management in the 1960s and 1970s, states became involved in local planning. Bollens (1992) argued that there is no uniform explanation for centralization of state and local authority to control regional or community growth management. However, he argued that transfer of authority from the local to state level is due to unwillingness of local governments to deal adequately with growth issues and potentially overlapping conflicts between state and local constituencies' preferences regarding environment protection (Bollens, 1992, p. 456).

Park, Kwak, and Kwon (2012) tested local zoning decisions affected by state-level efforts at smart growth management. They argued that local land use policies connected with "not in my back yard" issues such as development of affordable housing and waste management facilities have to be regulated by state-level institutions (Park, Kwon, \& Lee, forthcoming). This implies that, when local governments face conflicts between development and environmental protection, the role of state government is important to bring the collective benefits from the aggregated actions for environmental protection. That is, when local governments are unwilling to establish land use policies that are not related to their own preferences but to region-wide benefits, state-level institutions are necessary to promote local policies that are coordinated with state landuse planning objectives.

This implies that state governments become strongly involved when local growth policies generate negative externalities and shared solutions are needed to increase regional benefits. State policies can constrain local government actions. State-level choices prescribe what actions are required, prohibited, and permitted to local actors (Ostrom, 1990). Anthony (2004) has also argued that growth management programs require all local governments to adopt their practices in order to distribute the benefits of their positive effects to all of a state's residents. In line with this argument, state legislation can minimize the likelihood of negative externalities from growth orientation, assuming that the state holds strong powers over local land development policies.

With respect to the context of state governmental involvement in local planning and land use policies to address negative effects, it is clear that a hierarchical government structure is exercised in local land use policy. Within the state growth management stream, land use and development have been considered at all levels of governmentlocal, regional, state, and even federal. In Managing Community Growth, Kelly (1994) argued that the "state's new policy has the potential to influence the development decisions made by local government." Thus, smart growth efforts by state government influence development decisions and implementation by local government.

In terms of hierarchy, local governments depend on the state government for financial support and regulation and in other ways. This is because the local units are 
nested in the state, and areas from the same state are likely to follow similar policies. Thus, state-level contextual variables constitute an additional explanation for variation among county units.

Policy outcomes depend on the substantive rules' provisions (McCabe \& Feiock, 2005). Growth management by government officials is largely influenced by the structure of programs related to open space conservation. States have pursued different approaches to smart growth and defined it in different ways.

Smart growth can be defined in terms of two broad categories: land preservation and inner-city redevelopment (O'Connell, 2009). Open space preservation is an essential element of the smart growth movement. Downs (2005, p. 376) noted that without advocacy and substantial support by state government, smart growth cannot be realized, because "only the state government has the Constitutional power to shift authority over certain types of land use planning from local governments to regional or state wide agencies with the scope to carry out many smart growth policies." Thus, state smart growth efforts with more intensive and broader programs related to open space preservation are more likely to influence open space preservation efforts by county governments.

Hypothesis 2-1: State smart growth efforts with broader programs related to open space conservation will increase counties' open space preservation.

In addition, state growth management has specific consistency requirements and enforcement mechanisms, although these vary from state to state. Vertical consistency is the requirement for local plans to be consistent with state-level policy objectives. Horizontal consistency is the requirement for local plans to be compatible with other local plans. Internal consistency is the requirement for local plans to be consistent with development regulations. In a study of the impacts of state growth management programs, Carruthers (2002) found that "state growth management programs with strong consistency requirements and enforcement mechanisms hold much promise for reducing urban sprawl, while programs that do not require consistency and/or have weak enforcement mechanisms may inadvertently contribute to it.

Howell-Moroney (2007) argued that states that have the strongest growth management succeed in reducing urban sprawl and increasing population density. Therefore, state involvement through state growth management with stronger consistency is more likely to influence open space preservation by county governments.

Among states that require local government to adopt a comprehensive plan, a few states require local plans to address specific elements such as housing, economic development, transportation, air quality, and open space preservation. Thus, states 
requiring local plans to contain a specific element on open space preservation are more likely to influence open space preservation by county governments.

Hypothesis 2-2: Strong state involvement in local planning will increase counties' open space preservation.

Hypothesis 2-3: A state requirement for local plans to address open space preservation will increase counties' open space preservation.

\section{DATA AND METHODS}

\section{Data and Measurement}

To investigate the effects of state smart growth management on open space preservation, the study used the 2003 County Open Space Survey conducted by the National Association of Counties. Surveys were distributed to 1,298 of the 2,993 counties in all states except Connecticut, Maine, Massachusetts, New Hampshire, Rhode Island, and Vermont (these states do not implement land use policies at the county level). A total of 544 surveys were returned, for a response rate of about 42 percent. $^{1}$

The dependent variable was defined by how many acres of land had been protected or acquired as public open space. This information was recoded as ordinal categories. Although 544 surveys in 43 states were returned, this study used the responses of 540 counties from 39 states, since each state-level response needed more than two countylevel observations per state in order to use hierarchical linear modeling. Responses of "no answer" and "don't know" were also dropped, bringing the total number of counties included in the study to 335 . Table 1 indicates the number of acres of open space preserved within the last 10 years.

Independent variables were collected for the year 2002 from multiple data sources: survey items, the Public Law Research Institute's Smart Growth, Growing Smart Legislative Guidebook, the National Association of Counties Land Trust Alliance, and the US Census. Institutional variables included the form of government (coded 1 if the county had the manager form of government and 0 for all other types of government),

1. This sample might underrepresent some states and types of counties. However, the survey is the first to collect data nationwide at the county level and provides unique information that could not be collected from other archival sources. This survey was already used in a published article and dissertation (Matsumoto, 2005; Smith, 2008). Thus, its use can be justified despite the potential problem of sample representativeness. 
Table 1. Open Space Preserved within the Last 10 Years

\begin{tabular}{l|c|c|c}
\hline Number of acres & Frequency & Category code & Percent \\
\hline N/A & 167 & Dropped & 30.93 \\
\hline 0 & 27 & 1 & 5.00 \\
\hline $1-100$ & 57 & 2 & 10.56 \\
\hline $101-1,000$ & 119 & 3 & 22.04 \\
\hline $1,001-10,000$ & 80 & 4 & 14.81 \\
\hline $10,001-30,000$ & 33 & 5 & 6.11 \\
\hline$>30,000$ & 19 & 6 & 3.52 \\
\hline Don't know & 38 & Dropped & 7.04 \\
\hline Total & 540 & 335 & 100 \\
\hline
\end{tabular}

size of commission (number of commissioners), revenue sources (number of sources the county used to fund land preservation), dedicated offices (number of county offices or departments involved in efforts to plan, develop, acquire, or protect open space), and networks (number of groups that a county government cooperated with to preserve land).

Political economy variables included the strength of environmental interests (number of land trusts) and strength of developmental interests (percentage of county businesses involved in construction or real estate). Local political context variables included population growth (percentage of change between 1990 and 2000), white population (as a percentage of total population), education (percentage of the population having a bachelor's or higher degree), income (natural log of median income), population density (number of people per square mile), and the county's total land area.

State-level predictors included three variables: state smart growth efforts, strength of state involvement, and state requirement for an open space element in local plans. Data on state smart growth efforts were drawn from Smart Growth: State by State, conducted by the Public Law Research Institute in 2002. In that study, smart growth was defined with four primary elements: "(1) eliminating state subsidies that promote sprawl, (2) promoting infill development, (3) preserving farmland, open space, and areas of environmental and recreational value, and (4) supporting local planning by providing financial and technical assistance to local encouraging them to enter into regional planning agreements. This study used the third and fourth elements to measure state smart growth efforts, since those elements are directly related to local open space preservation. To measure state smart growth efforts, the number of programs that a state was implementing were counted. 
Table 2. Strength of State Involvement in Local Planning

\begin{tabular}{l|c|c}
\hline & Frequency & Percent \\
\hline Weak & 18 & 46.2 \\
\hline Moderate & 16 & 41.0 \\
\hline Strong & 5 & 12.8 \\
\hline Total & 39 & 100.0 \\
\hline
\end{tabular}

The strength of state involvement in local planning was measured in the Growing Smart Legislative Guidebook (2002) by the following criteria: (1) similarity of the best statute on local planning to the 1920s planning laws; (2) whether the state's best planning statute mandates local planning; (3) whether the state requires horizontal and/or vertical consistency in planning by different government jurisdictions; (4) whether the state has a land use plan or planning policies; and (5) whether the state certifies, approves, or acknowledges local plans as consistent with state planning policies, goal, standards. If the state's role met none of these criteria, it was coded 1. If it met one criterion, it was coded 2 . If it met three to five of the criteria, it was coded by 3 (table 2 ).

Data on state requirements for an element of open space preservation in local plans were also drawn from the Growing Smart Legislative Guidebook. If a state required local planning to address open space preservation, it was coded 1 ; if not, it was coded 0 (table 3).

Next, three new variables were created based on the above three variables to more accurately capture state government involvement in open space preservation by local government. Measuring smart growth efforts by the number of programs state government implements is too broad to capture the strength of state government involvement. This was measured by state involvement in local planning more broadly, not only in open space preservation. Regarding a state requirement that local planning address open space preservation, this element is optional even when a state requires its local governments to create a comprehensive plan. Thus, this study combined three variables to capture the strength of state government involvement in local government: (1) smart

Table 3. State Requirement for Local Plans to Address Open Space Preservation

\begin{tabular}{l|c|c}
\hline & Frequency & Percent \\
\hline Required & 22 & 56.4 \\
\hline Not required & 17 & 43.6 \\
\hline Total & 39 & 100.0 \\
\hline
\end{tabular}


growth efforts combined with state involvement, (2) smart growth efforts combined with a required element of open space preservation, and (3) state involvement combined with a required element of open space preservation.

Table 4 presents descriptive statistics. These observations of state and county governments are different from the initial observations of the survey data because the independent variables at the county level have missing data, and this affected the observations regarding state governments.

Table 4. Descriptive Statistics

\begin{tabular}{|c|c|c|c|c|c|}
\hline & Observations & Mean & $\begin{array}{l}\text { Standard } \\
\text { deviation }\end{array}$ & Minimum & Maximum \\
\hline \multicolumn{6}{|l|}{ Dependent variable } \\
\hline Preserved open space & 325 & 3.28 & 1.26 & 1.00 & 6.00 \\
\hline \multicolumn{6}{|l|}{ Independent variables: state-level predictors } \\
\hline Smart growth efforts * state involvement & 36 & 3.22 & 3.60 & 0.00 & 15.00 \\
\hline $\begin{array}{l}\text { Smart growth efforts * required open space } \\
\text { element }\end{array}$ & 36 & 0.86 & 1.36 & 0.00 & 5.00 \\
\hline $\begin{array}{l}\text { State involvement * required open space } \\
\text { element }\end{array}$ & 36 & 1.06 & 1.07 & 0.00 & 3.00 \\
\hline \multicolumn{6}{|l|}{ Independent variables: local-level predictors } \\
\hline Form of government & 325 & 0.55 & 0.50 & 0.00 & 1.00 \\
\hline Size of commission & 325 & 7.62 & 7.11 & 1.00 & 37.00 \\
\hline Revenue sources & 325 & 2.43 & 1.63 & 0.00 & 8.00 \\
\hline Dedicated office & 325 & 2.25 & 1.12 & 0.00 & 7.00 \\
\hline Network & 325 & 4.25 & 2.71 & 0.00 & 10.00 \\
\hline Environmental interests & 325 & 2.93 & 3.44 & 0.00 & 25.00 \\
\hline Development interests & 325 & 19.20 & 4.05 & 5.42 & 33.00 \\
\hline Population & 325 & 11.28 & 1.26 & 7.92 & 16.07 \\
\hline Population growth & 325 & 20.88 & 17.56 & -13.25 & 103.16 \\
\hline White population & 325 & 85.82 & 12.57 & 27.50 & 98.90 \\
\hline Education & 325 & 21.74 & 9.28 & 3.90 & 57.10 \\
\hline Income & 325 & 10.62 & 0.22 & 10.05 & 11.30 \\
\hline Population density & 325 & 297.67 & 503.92 & 1.79 & $3,775.54$ \\
\hline Land area & 325 & $1,097.67$ & $1,819.81$ & 105.65 & $18,617.42$ \\
\hline
\end{tabular}




\section{Methods}

Since the analytical model modifies two different units (state and county government) into a single analytical framework, this study employed hierarchical linear modeling. This is a useful tool that can address nested structures and explain and verify the relationships between groups (for example, random effect) and within groups (fixed effect) (Osborne, 2000; Raudenbush \& Bryk, 2002).

Analytical strategies for dealing with cross-sectional data can be categorized as aggregation and disaggregation. County-level data can be aggregated to the state level, but this leads to analytical problems such as loss of counties' variability and substantial changes in counties' protected land areas. State-level data can be disaggregated to the county level, but this leads to the analytical problem of non-independence of observations, given that all counties within a particular state have identical scores on a predictor (Osborne, 2000, p. 2). These analytical problems arise from the differences in means and standard errors across levels. By constructing the pure effect of predictors and the effect of residual and preventing misinterpretation of predictors' coefficients (Thum, 1997), hierarchical linear modeling resolves the problems of aggregation and disaggregation of data, combining high-level (state) units with low-level (county) units for one unit level analysis.

This study tested two models: the unconditional model and the simple randomintercept model. The unconditional model, which does not include state-level predictors, is compared with the simple random-intercept model, which includes state-level predictors, in order to calculate the proportion of variances reduced by state-level predictors. The equations of the two models are as follows:

- Unconditional model

$\mathrm{y}($ Preserved Land $)=\mathrm{r}_{0}+\mathrm{r}_{1}$ (Form of Government $)+\mathrm{r}_{2}$ (Size of Commission) $+r_{3}$ (Revenue Sources) $+r_{4}$ (Networks) $+r_{6}$ (Environmental Interests)

$+r_{7}$ (Development Interests) $+r_{8}$ (Population) $+r_{9}$ (Population Growth)

$+r_{10}$ (White) $+r_{11}$ (Eduction) $+r_{12}$ (Income $)+r_{13}$ (Density) $+r_{14}$ (Land Area)

$+\mathrm{u}_{0}+\mathrm{R}$

- Simple random intercept model

$\mathrm{y}($ Preserved Land $)=\mathrm{r}_{0}+\mathrm{r}_{01}$ (Smart Growth efforts * State Involvement)

$+r_{02}$ (Smart Growth Efforts * Element of Open Space)

$+r_{03}$ (State Involvement $*$ Element of Open Space) $+r_{1}$ (Form of Government)

$+r_{2}$ (Size of Commission $)+r_{3}$ (Revenue Sources $)+r_{4}$ (Dedicated Office)

$+r_{5}$ (Networks) $+r_{6}$ (Environmental Interests $)+r_{7}$ (Development Interests) 


$$
\begin{aligned}
& \left.\left.+r_{8} \text { (Population }\right)+r_{9} \text { (Population Growth }\right)+r_{10}(\text { White })+r_{11} \text { (Education) } \\
& +r_{12}(\text { Income })+r_{13} \text { (Density) }+r_{14}(\text { Land Area })+u_{0}+\mathrm{R}
\end{aligned}
$$

where $y$ is the predicted value of the counties' characteristics, $r_{1}$ through $r_{14}$ are the coefficients that represent the effects of county-level predictors, $r_{01}$ to $r_{03}$ are the coefficients that represent the effects of state-level predictors, and $\mathrm{u}_{0}$ is a random error in the state-level equation.

\section{ANALYSIS AND FINDINGS}

Unlike traditional regression, which has to satisfy assumptions of linearity, normality, homoscedasticity, and independence of errors, hierarchical linear modeling only has to satisfy assumptions of linearity and normality, since it modifies the presumptions of homoscedasticity and independence of errors. For the test of assumptions, this study tested the residual analysis with 11resid and fitval plots and established that the difference between fitted and observed values for each county showed the normal distribution (figure 1).

One-way ANOVA was also performed in order to examine the variation of the outcome: local protected or acquired open space areas. This analysis tested the assumption that state and local governments are hierarchically structured in examining local open space preservation. The average preserved open space varied by state

Figure 1. Test of assumptions
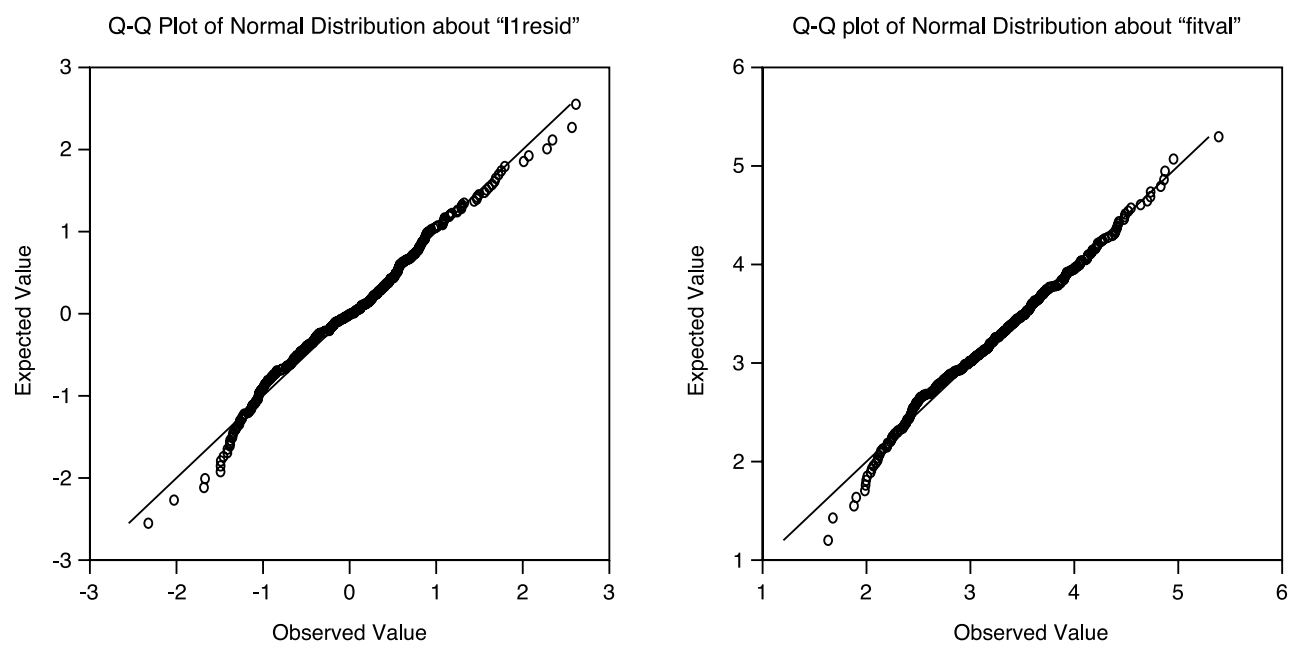

The Korean Journal of Policy Studies 
Table 5. One-Way ANOVA of Local Open Space Preservation

\begin{tabular}{c|c|c|c|c}
\hline Fixed effect & Coefficient & Se & T-ratio & P-value \\
\hline Average preserved open space, $r_{0}$ & 3.28 & 0.096 & 34.032 & 0.000 \\
\hline Random effect & \multicolumn{3}{|c}{ Variance component } & P-value \\
\hline State mean, $u_{0}$ & \multicolumn{3}{|c|}{0.147} & 0.000 \\
\hline County effect, $\mathrm{R}$ & \multicolumn{3}{|c}{1.430} \\
\hline
\end{tabular}

(table 5) with a coefficient of 3.28, meaning that counties on average preserved between 101 and 1,000 acres of open space. Intra-class correlation was also calculated, using the equation $\hat{\rho}=\hat{\tau}_{00} /\left(\hat{\tau}_{00}+\hat{\sigma}^{2}\right)$, with a result of about 9.3 percent, meaning that the average preserved open space was explained by state differences in terms of 9.3 percent of variance.

Table 6. Statistical Results of Unconditional and Simple Random Intercept Models

\begin{tabular}{l|c|c}
\hline \multicolumn{1}{c|}{ Variables } & $\begin{array}{c}\text { Unconditional model } \\
\text { Coefficient (p-value) }\end{array}$ & $\begin{array}{c}\text { Simple random } \\
\text { intercept model } \\
\text { Coefficient (p-value) }\end{array}$ \\
\hline Intercept (average local protected areas) & $-7.221(0.081)$ & $-8.194(0.039)$ \\
State effects & - & $0.039(0.015)$ \\
Smart growth efforts * state involvement & - & $-0.102(0.249)$ \\
Smart growth efforts * required open space element & - & $0.198(0.023)$ \\
State involvement * required open space element & & \\
Local effects & & \\
1. Institutions: & $-0.219(0.086)$ & $-0.220(0.053)$ \\
Form of government & $-0.005(0.516)$ & $-0.000(0.925)$ \\
Size of commission & $0.139(0.020)$ & $0.131(0.023)$ \\
Revenue source & $0.008(0.844)$ & $-0.008(0.835)$ \\
Dedicated office & $0.136(0.000)$ & $0.136(0.000)$ \\
Networks & & \\
2. Political economy: & $0.035(0.004)$ & $0.034(0.008)$ \\
Environmental interests & $0.020(0.199)$ & $0.023(0.166)$ \\
Development interests & & \\
3. Community and physical characteristics: & $0.200(0.013)$ & $0.197(0.013)$ \\
Population & $-0.002(0.486)$ & $-0.004(0.261)$ \\
Population growth & $0.006(0.175)$ & $0.007(0.177)$ \\
White population & $-0.011(0.143)$ & $-0.008(0.299)$ \\
Education & $0.631(0.129)$ & $0.685(0.083)$ \\
Income & $-0.000(0.085)$ & $-0.000(0.066)$ \\
Population density & $0.000(0.001)$ & $0.000(0.000)$ \\
Land area & & \\
\hline & & \\
\hline
\end{tabular}


Table 6 summarizes the results of analysis using the unconditional model and the simple random-intercept model. Several significant predictors were found at the county government level. Within the institutional indicators, form of government, resources, and network had an effect on the amount of open space preserved. The manager form of government, surprisingly, was negatively associated with open space preservation. Possession of greater revenue sources was positively associated with open space preservation.

Among institutional indicators, networks were positively significant, meaning that networks with other organizations such as private land trusts, environmental organizations, state agencies, and regional planning and development agencies are highly related to increased open space preservation. Meanwhile, size of commission and dedicated office had no significant influence on open space preservation.

Regarding the indicators of political economy, environmental interest groups are positively associated with open space preservation, while development interest groups do not influence it. There is evidence that environmental interest groups measured by the number of land trusts increase open space preservation.

Among community characteristics, population, population density, and land area were statistically significant. Population and land area were positively associated with open space preservation, as expected, while population density was negatively related to open space preservation, which was unexpected. Population growth, white population as a percentage of total population, education, and median income did not affect open space preservation.

In terms of state-level predictors, state smart growth efforts combined with strong state involvement in local planning practices and a required open space element combined with strong state involvement were positively associated with open space preservation. Interestingly, state smart growth efforts combined with a required open

Table 7. Random Effect of Unconditional and Simple Random Intercept Models

\begin{tabular}{l|c|c|c}
\hline Unconditional model & Variance component & Df & P-value \\
\hline Random effect & 0.0823 & 35 & 0.000 \\
\hline State mean, $u_{0}$ & 1.022 & & \\
\hline County effect, $\mathrm{R}$ & \multicolumn{3}{|l}{} \\
\hline Simple random intercept model & Variance component & Df & P-value \\
\hline Random effect & 0.069 & 35 & 0.000 \\
\hline State mean, $u_{0}$ & 1.018 & & \\
\hline County effect, $\mathrm{R}$ & & & \\
\hline
\end{tabular}


space element had no significant influence on open space preservation.

Regarding state-level effects, the random effects were statistically significant, and state intervention in county-level open space preservation varied across states (table 7).

In addition to the random effect, comparing results of variance components between the two hierarchical linear models predicted the extent to which state-level effects explain the variability of county open space preservation, while controlling for countylevel predictors. Regarding two statistically significant state-level predictors, there is about 17.1 percent variance reduction in more explaining difference of average county open space preservation across states. Reduced variance was calculated as follows: (unconditional $\mathrm{u}_{0}-$ simple random intercept $\mathrm{u}_{0}$ ) / unconditional $\mathrm{u}_{0}$.

\section{DISCUSSION}

The goal of this study was to explore the dynamics of open space preservation in terms of hierarchical governance and the political process at multiple levels and different spatial and temporal scales. With advanced hierarchical linear modeling, which combines low-level units and high-level units into a single model, this study found important factors affecting open space preservation at both state and county levels.

Understanding the hierarchy of intergovernmental relationships is important to understanding environmental preservation in general and open space preservation in particular. Strong intervention by state government leads local governments to protect more open space. This result implies that state policies and rules constrain local government actions. Along with this, smart growth efforts by state government with intensive involvement in local planning practices have had more success in increasing open space preservation by county governments. Theoretically and empirically, this means that the land use planning objectives of state government are additional dimensions to take into account in variations in local open space preservation.

These results also have practical implications for state government. Recently, state governments have reduced and even eliminated programs for local open space preservation due to the economic crisis and budget deficits, while many practitioners and professionals recognize the necessity of open space preservation for future community development and planning practices. For example, Florida eliminated its annual funding for local government relating to land preservation in 2009 and allocated only $\$ 15$ million in 2010, which is just 5 percent of the traditional million. Under the Florida Community Trust land acquisition program, more than 2 million acres were purchased for preservation, which is quite successful (Lee, 2011). Low-income counties that lack the resources to preserve land have submitted applications to the Florida Community 
Trust and focused on land development.

This example supports the idea that the state role is more important in counties with limited resources that compete with other counties for economic development. Regarding the long-term distributive benefits of environmental preservation, state governments need to implement various programs, support local planning by providing financial and technical assistance, and require local planning initiatives to include an element of open space preservation.

On the other hand, the effect of the form of government is unclear. Theoretically, the county manager form of government would be more likely to preserve open space. However, this depends on practical conditions. As in the question of state government intervention, if counties lack revenue and are suffering from the current economic crisis, county policies are likely to focus on development. Under such conditions, a county manager is less likely to preserve open space and more likely to develop land.

In addition to formal institutions, networks as informal institutions are a key driver of open space preservation. Vertical partners such as federal and state agencies, and horizontal partners such as land trusts, environmental organizations, and other nonprofit organizations, are important sources of funding and information that can support open space preservation. Likewise, this result has important implications for local government staff. Partnership with state agencies makes land transactions easier, because state agencies have more credibility and more well-established programs and staffs (Matsumoto, 2005). Thus, county government staff should identify opportunities for collaboration and build strong relationships to enhance their success in open space preservation, even though there are some challenges in building and maintaining these networks.

There are also implications regarding interest groups, community, and physical characteristics. Organized environmental interests advocate environmental amenities in their community, while development interests narrowly focus on land development and utilization. This suggests that environment-oriented interest groups are more powerful to make their voices heard for preserving land in counties, since land preservation is related to the interests of environmental protection.

According to this perspective, population size and density are important considerations in the preservation of environmental amenities in a county. When counties have had a rapid growth rate and population pressure and have already secured enough development, they tend to control growth and preserve the environment. Another important consideration is the site of open space preservation, which generally takes place in unincorporated rural areas that have lower land prices and larger parcels of undeveloped land (Mumford \& Myszewski, 2004).

Regarding the effects of population density, this study found two conflicting impli- 
cations. High population density in counties is likely to mean that much land and open space has already been developed and that the counties make protecting the environment and preserving land a priority. However, when counties have a high population density in urban areas, they resolve this by developing more suburban areas, resulting in use of suburban land for low-density development. However, this study found that highdensity counties were less likely to preserve open spaces in order to redirect urbanized sprawl, while they were concerned about environmental protection.

This study had some limitations. A larger number of observations and longitudinal studies may produce more accurate estimates of the variation in counties' open space preservation than cross-sectional studies with repeated measurements. While this study generalized the number of groups related to open space preservation as a network, this may not be enough to explain the dynamic relations involved. Thus, there is a need to develop network indicators, for example using actual agreements between groups and nonprofit organizations' commitments and contracts, or to study multiple cooperative relations through mixed methods and case studies.

\section{REFERENCES}

Anglin, R. 1990. Diminishing utility: Effects on citizen preferences for local growth. Urban Affairs Quarterly, 25: 684-696.

Anthony, J. 2004. Do state growth management regulations reduce sprawl? Urban Affairs Review, 39(3): 376-397.

Anthony, J. 2008. Exploring causes of smart growth policy adoption: Many challenges persist. Social Science Quarterly, 89(5): 1374-1377.

Baldassare, M., \& Protash, W. 1982. Growth controls, population growth, and community satisfaction. American Sociological Review, 47: 339-346.

Bolen, E., Brown, K., Kiernan, D., \& Konschuk, K. 2001. Smart growth: State by state. Hastings: University of California College of the Law.

Bollens, S. 1992. State growth management: Inter-governmental frameworks and policy objectives. Journal of the American Planning Association, 58: 454-466.

Bosselman, F. P., \& Callies, D. L. 1971. The quiet revolution in land use control. Washington, DC: Council on Environmental Quality and Council of State Governments.

Brent, S. S., \& Lovrich, N. P. 2000. Growth management policy and county government: Correlates of policy adoption across the United States. State and Local Government Review, 32(7): 7-19.

Burt, R. S. 1992. Structural holes: The social structure of competition. Cambridge, 
MA: Harvard University Press.

Burt, R. S. 2000. The network structure of social capital. In R. I. Sutton \& B. M. Staw (eds.), Research in organizational behavior (pp. 345-423). Greenwich, CT: JAI Press.

Carruthers, J. I. 2002. The impacts of state growth management programmes: A comparative analysis. Urban Studies, 39(11): 1959-1982.

Clingermayer, J. C., \& Feiock, R. C. 2001. Institutional constraints and local policy choices: An exploration of local governance. Albany: State University of New York Press.

Cooter, R. 2000. The strategic constitution. Princeton, NJ: Princeton University Press.

Denzau, A., \& Weingast, B. 1982. Recent developments in zoning and property rights. Forward: The political economy of land use regulation. Urban Law Annual, 23: 385-405.

DeSantis, V., \& Renner, T. 1994. The impact of political structures on public policies in American counties. Public Administration Review, 54(3): 291-295.

Downs, A. 1999. Some realities about sprawl and urban decline. Housing Policy Debate, 10: 955-974.

Dunlap, R. E., \& Mertig, A. 1992. American environmentalism. Bristol, PA: Taylor and Francis.

Erickson, D. L. 2006. Metro-green: Connecting open space in North American cities. Washington, DC: Island Press.

Feiock, R. C. 1994. The political economy of growth management. American Politics Quarterly, 22: 208-220.

Feiock, R. C. 2003. Politics, governance, and the complexity of local land use regulation. Urban Studies, 41(2): 363-377.

Gale, D. 1992. Eight state sponsored growth management programs-A comparative analysis. Journal of the American Planning Association, 58: 425-439.

Gillham, O. 2002. The limitless city: A primer on the urban sprawl debate. Washington, DC: Island Press.

Green, G. P., Marcouiller, D., Deller, S., Erkkila, D., \& Sumathi, N. R. 1996. Local dependency, land use attitudes, and economic development: Comparison between seasonal and permanent residents. Rural Sociology, 61(3): 427-445.

Healy, R. G., \& Rosenberg, J. S. 1979. Land use and the states (2nd ed.). Baltimore: Johns Hopkins University Press.

Howell-Moroney, M. 2004. Community characteristics, open space preservation and regionalism: Is there a connection? Journal of Urban Affairs, 26(1): 109-118.

Howell-Moroney, M. 2007. Studying the effects of the intensity of US state growth management approaches on land development outcomes. Urban Studies, 
44(11): 2163-2178.

Kelly, E. D. 1994. Managing community growth: Policies, techniques, and impacts. Westport, CT: Praeger Press.

Ketcham, P., \& Seigal, S. 1991. Managing growth to promote affordable housing: Revisiting Oregon's Goal 10. Portland: 1000 Friends of Oregon.

Kline, J. D. 2000. Comparing states with and without growth management: Analysis based on indicators with policy implications comment. Land Use Policy, 17: 349-355.

Koestler, A. 1973. The tree and the candle. In Gray, W., \& Rizzo, N. D. (eds.), Unity through diversity, part 1 (pp. 287-314). New York: Gordon and Breach Science Publishers.

Lee, S. J. 2011. Environmental local public goods: Open space preservation and multilevel analysis. Doctoral dissertation, Florida State University.

Lewis, P., \& Neiman, M. 2002. Cities under pressure: Local growth controls and residential development policy. San Francisco: Public Policy Institute of California.

Lin, N. 2005. Network theory of social capital. In Castiglione, D., Van Deth, J., \& Wolleb, G. (eds.), Handbook of social capital. Oxford: Oxford University Press.

Logan, J., \& Molotch, H. 1987. Urban fortunes: The political economy of place. Berkeley: University of California Press.

Lubell, M., Feiock, R. C., \& Ramirez, E. 2005. Political institutions and conservation by local governments. Urban Affairs Review, 40(6): 706-729.

Maser, S., Riker, W., \& Rosett, R. 1977. The effects of zoning and externalities on the price of land: An empirical analysis of Monroe County, NY. Journal of Law and Economics, 20: 111-132.

Matsumoto, Y. 2005. Local land conservation efforts: A study of selected county programs in the United States. Master's thesis, University of Washington.

McCabe, B. C., \& Feiock, R. C. (2005) Nested levels of institutions: State rules and city property taxes. Urban Affairs Review, 40(5): 634-654.

McQueen, M., \& McMahon, E. 2003. Land conservation financing. Washington, DC: Island Press.

Morgan, D., \& Kickham, K. 1999. Changing the form of county government: Effects on revenue and expenditure policy. Public Administration Review, 59(4): 315-324.

Mumford, K., \& Myszewski, M. 2004. County open space protection: A survey of the current state of open space protection efforts by America's counties. Athens, GA: National Center for the Survey of Counties.

Nalbandian, J. 1989. The contemporary role of city managers. American Review of Public Administration, 19: 261-277.

Navarro, P., \& Carson, R. 1991. Growth controls: Policy analysis for the second 
generation. Policy Sciences, 24: 127-152.

Nelson, A. C. 1999. Comparing states with and without growth management regulations based on indicators with policy implications. Land Use Policy, 16: 121-127.

Nelson, A. C., Pendall, P., Dawkins, C. J., \& Knaap, G. J. 2004. The link between growth management and housing affordability: The academic evidence. In Downs, A. (ed.), Growth management and affordable housing (pp. 117-157). Washington, DC: Brookings Institution Press.

Nolon, J. R. 2006. Comparative land use law and global sustainable development. Cambridge: Cambridge University Press.

O'Connell, L. 2009. The impact of local supporters on smart growth policy adoption. Journal of the American Planning Association, 75(3): 281-291.

Osborne, J. W. 2000. Advantages of hierarchical linear modeling. Practical Assessment, Research \& Evaluation, 7(1). Retrieved November 11, 2010 from http://PARE online.net/getvn.asp? $\mathrm{v}=7 \& \mathrm{n}=1$.

Ostrom, E. 1990. Governing the commons. Cambridge: Cambridge University Press.

Ostrom, E. 2005. Understanding institutional diversity. Princeton, NJ: Princeton University Press.

Park, S.-C., Kwak, C.-K., \& Kwon, S.-W. 2012. Residential development and hierarchical governance: Multifamily housing and multilevel analysis. Korean Journal of Policy Studies, 27(2): 1-22.

Park, S.-C., Kwon, S.-W., \& Lee, S.-J. forthcoming. Participants in local zoning for multifamily housing development and decision delay: Transaction cost and hierarchical governance. International Journal of Public Administration.

Press, D. 2002. Saving open space: The politics of local preservation in California. Berkeley: University of California Press.

Press, D. 2003. Who votes for natural resources in California? Society and Natural Resources, 16(9): 835-846.

Protash, W., \& Baldassare, M. 1983. Growth policies and community status. Urban Affairs Quarterly, 18, 397-412.

Raudenbush, S. W., \& Bryk, A. S. 2002. Hierarchical linear models: Applications and data analysis methods (2nd ed.). Thousand Oaks, CA: Sage.

Romero, F., \& Liserio, A. 2002. Saving open spaces: Determinants of 1998 and 1999 antisprawl ballot measures. Social Science Quarterly, 83(1): 341-352.

Squires, G. 2002. Urban sprawl-causes, consequences and policy responses. Washington, DC: Urban Institute.

Steinacker, A. 1998. Economic restructuring in U.S. cities, suburbs, and non-metropolitan areas, 1977-1992. Urban Affairs Review.

Thum, T. M. 1997. Hierarchical linear models for multivariate outcomes. Journal of 
Educational and Behavioral Statistics, 22(1): 77-108.

Weitz, J. 1999. From quiet revolution to smart growth: State growth management programs, 1960 to 1999. Journal of Planning Literature, 14: 267-338.

\section{APPENDIX: RESULTS OF HIERARCHICAL LINEAR MODELING}

\begin{tabular}{l|l|l}
\hline \multicolumn{1}{c|}{ Factors affecting local open space preservation } & $\begin{array}{c}\text { Unconditional } \\
\text { model }\end{array}$ & $\begin{array}{c}\text { Simple random- } \\
\text { intercept model }\end{array}$ \\
\hline Smart growth efforts ${ }^{*}$ state involvement & Direction & \\
\hline Smart growth efforts ${ }^{*}$ required open space element & & Positive \\
\hline State involvement ${ }^{*}$ required open space element & & Insignificant \\
\hline Form of government & Negative & Positive \\
\hline Size of commission & Insignificant & Insignificant \\
\hline Revenue source & Positive & Positive \\
\hline Dedicated office & Insignificant & Insignificant \\
\hline Networks & Positive & Positive \\
\hline Environmental interests & Positive & Positive \\
\hline Development interests & Insignificant & Insignificant \\
\hline Population & Positive & Positive \\
\hline Population growth & Insignificant & Insignificant \\
\hline White population & Insignificant & Insignificant \\
\hline Education & Insignificant & Insignificant \\
\hline Income & Insignificant & Positive \\
\hline Population density & Negative & Negative \\
\hline Land Area & Positive & Positive \\
\hline & & \\
\hline
\end{tabular}

